\title{
In vitro antioxidant and lipase inhibitory activities of Makgeolli supplemented with Jeju Camellia Mistletoe (Korthalsella japonica Engl.) during fermentation
}

\author{
Eun Hye Ko ${ }^{1} \cdot$ Eun Mi Park ${ }^{1} \cdot$ Min Young Kim ${ }^{1}$ (D)

\section{제주 동백나무 겨우살이를 첨가한 막걸리의 항산화 및 항비만 활성}

고은혜 ${ }^{1}$ - 박은미 ${ }^{1}$ · 김민영 ${ }^{1}$

Received: 12 June 2017 / Accepted: 1 August 2017 / Published Online: 30 September 2017

(C) The Korean Society for Applied Biological Chemistry 2017

\begin{abstract}
The objective of the present study was to evaluate in vitro antioxidant activity, antioxidant content and pancreatic lipase inhibitory activities of Makgeolli supplemented with 0, 1, 2, and $4 \%$ (w/v) Jeju camellia mistletoe during fermentation. Total phenolic and flavonoid contents tended to increase as content of Jeju camellia mistletoe increased. Supplementation with Jeju camellia mistletoe resulted in a significant increase in the scavenging capacities of 1,1-diphenyl-2-picrylhydrazyl, hydrogen peroxide, nitric oxide and superoxide anion radicals, and reducing power activity. Moreover, pancreatic lipase inhibitory activity was significantly elevated by Jeju camellia mistletoe addition. These results suggest that Jeju camellia mistletoe is considered to be a good material to improve antioxidant and pancreatic lipase inhibitory activities of makgeolli.
\end{abstract}

Keywords Antioxidant activity · Jeju camellia mistletoe · Makgeolli $\cdot$ Pancreatic lipase inhibitory activity · Total phenolic and flavonoid contents

Eun Hye Ko and Eun Mi Park are contributed equally.

Min Young Kim $(\triangle)$

E-mail: jeffmkim@jejunu.ac.kr

${ }^{1}$ Toxicology Laboratory, Major in Biomaterials, SARI, Jeju National University, Jeju 690-756, Republic of Korea

This is an Open Access article distributed under the terms of the Creative Commons Attribution Non-Commercial License (http://creativecommons. org/licenses/by-nc/3.0/) which permits unrestricted non-commercial use, distribution, and reproduction in any medium, provided the original work is properly cited.

\section{서 론}

인류가 만든 가공 음료 중 가장 오래 된 술은 지역, 민족, 기 후, 풍토에 따라 독특한 주세법이 개발되면서 고유한 전통주로 서 발전하였다(Kim과 Eun 2012). 우리나라의 전통주인 막걸리 는 오미가 고루 조화되고 생효묘가 함유되어 있어 다른 주류와 비교할 수 없는 독특한 맛을 가지고 있다(Park 등, 2016). 또한 쌀을 원료로 누룩을 이용하여 빚는 발효 곡주로서 당질, 비타 민 B군 및 다양한 아미노산(valine, leucine, serine, proline, glycine)들이 풍부할 뿐만 아니라 영양가가 우수한 특징을 가지 고 있다(Baek 등, 2013). 막걸리는 멥쌀, 찹쌀, 소맥분 등을 주 로 사용하지만 옥수수, 고구마, 보리, 좁쌀, 블루베리, 울금 등 다양한 지역 특산물이 함유된 첨가 막걸리에 대한 개발 및 그 발효특성과 품질을 향상시키고자 하는 다양한 연구가 진행 되 고 있다(Kim과 Eun 2012; Baek 등, 2013; Choi 등, 2013).

겨우살이는 여러 종류의 나무를 숙주로 하여 수분과 영양분 등을 취하며 자체적으로 광합성을 하는 능력을 지닌 반기생성 식물로(Kang 등, 2016), Lectin, Amyrin, Viscine, Inositol 및 Flavonoids 등을 함유하여 콜레스테롤 저하, 혈압강하, 항균, 항 암 및 면역증강 등의 효능을 가진 것으로 알려졌지만(Park 등, 2003; Lee 등, 2010; Kang과 Chung 2012), 타 지역과 달리 독특한 기후와 토양을 지닌 제주도에서 서식하는 동백나무 겨 우살이를 이용한 가공식품이나 생리학적 활성에 대한 연구가 전무한 실정이다. 따라서 본 연구에서는 제주산 동백나무 겨우 살이의 부가가치를 향상시키고 전통주인 막걸리에 기능성을 부 여하기 위한 기초연구로 제주 전통 누룩과 쉰다리 제조 방법 을 응용하여 동백나무 겨우살이가 첨가된 막걸리를 제조하고 이에 대한 생리활성 성분과 항산화 및 항비만 활성을 조사하 였다. 


\section{재료 및 방법}

\section{실험재료}

본 실험에 사용한 동백나무 겨우살이는 제주 서귀포시 안덕면 에 위치한 카멜리아 힐에서, 막걸리를 제조하기 위한 쌀은 해 남군 화산농협미곡처리장에서 2016년 도정한 것을 구매하여 사 용하였다.

\section{제주 전통 누룩 제조}

제주시 조천읍 신촌리에서 직접 재배한 통밀을 사용하여 제주 전통방식으로 누룩을 제조하였다. 밀 $1 \mathrm{~kg}$ 을 달아 물로 세척한 다음 $200 \mathrm{~mL}$ 의 물을 가해 반죽하고 보자기를 깔아 눌러 담은 뒤 누룩의 모양을 잡고, 성형된 누룩을 트레이에 넣고 볏짚이나 마른 쑥 등을 같이 채워 넣어 $32-42{ }^{\circ} \mathrm{C}$ 온도의 전기 방석 위에 올려 놓고 천으로 덮어주었다. 누룩이 고루 발효 될 수 있도록 2-3일간 보관 상자 안의 누룩 위치를 서로 바꿔 주었으며, 15-20 일 정도 유지하여 누룩이 완전히 단단하게 마르면 공기가 통하 지 않게 잘 밀봉하여 보관 후 분쇄하여 분말을 제조하였다.

\section{막걸리 담금}

제주 동백나무 겨우살이 막걸리는 보통 5-7일 동안 발효시키는 일반 막걸리보다 발효시간이 짧고 알코올 함량이 낮은 제주 전 통 발효음료인 쉰다리 공정을 응용하여 제조하였다(Cho 등, 2014; Kim과 Park 2015). 쌀을 세척한 뒤 쌀 양의 1.5 배의 물 을 부은 후 밥솥을 이용하여 고두밥 $(2.5 \mathrm{~kg})$ 을 짓고, 누룩 $(75 \mathrm{~g})$ 과 물 $(5000 \mathrm{~mL})$ 을 넣고 혼합하여 $26^{\circ} \mathrm{C}$ 에서 48 시간 동안 1 차 발효시켰다. 1차 발효액 중량에 따라 $0,1,2$, 그리고 $4 \%(\mathrm{w} / \mathrm{v})$ 가 되도록 잘게 분쇄한 동백나무 겨우살이를 혼합하여 24시간 동안 2 차 발효시켜 막걸리를 제조하였다. 제조된 막걸리는 체 를 이용하여 불용물질을 제거한 후 $4,000 \mathrm{rpm}$ 으로 30 분 동안 원심분리 하여 상층액을 얻었으며, 이를 $0.45 \mu \mathrm{m}$ syringe filter 로 재차 여과하여 실험에 사용하였다.

\section{총 폴리페놀 및 플라보노이드 함량}

총 페놀 함량측정은(Kang과 $\mathrm{Kim} 2015)$ 시료 용액 $30 \mu \mathrm{L}$ 와 증 류수 $150 \mu \mathrm{L}, 95 \%$ 에탄올 $30 \mu \mathrm{L}, 50 \%$ Folin-Ciocalteu reagent $15 \mu \mathrm{L}$ 를 순서대로 첨가하여 잘 혼합하였다. 실온에서 5 분간 반 응시킨 후 $5 \% \mathrm{Na}_{2} \mathrm{CO}_{3} 30 \mu \mathrm{L}$ 를 첨가하고, 차광한 상태에서 1 시간 동안 실온에 방치한 후 microplate reader (Spectra MR, Dynex, VA, USA)를 이용하여 $725 \mathrm{~nm}$ 에서 흡광도를 측정하였 다. 이때 총 폴리페놀 함량은 gallic acid를 이용하여 작성한 표 준곡선을 통해 총 폴리페놀 함량(mg glallic acid equivalent/L) 을 구하였다.

총 플라보노이드 함량 측정은(Kang과 $\mathrm{Kim} 2015)$ 각 시료 $30 \mu \mathrm{L}$ 에 증류수 $120 \mu \mathrm{L}, 5 \% \mathrm{NaNO}_{2} 9 \mu \mathrm{L}$ 를 함께 혼합하여 실 온에서 6 분간 반응시킨 후 $10 \% \mathrm{AlCl}_{3} 9 \mu \mathrm{L}$ 를 첨가하여 다시 6 분간 반응시켰다. 이후 $1 \mathrm{M} \mathrm{NaOH} 60 \mu \mathrm{L}$ 및 증류수 $72 \mu \mathrm{L}$ 를 첨가한 후 실온에서 15 분간 반응시키고 $420 \mathrm{~nm}$ 에서 흡광도를 측정하였다. 표준물질로 rutin을 사용하여 총 플라보노이드 함량 (mg rutin equivalent/L)을 산출하였다.

\section{DPPH radical 소거 활성}

$\mathrm{DPPH}$ radical 소거 활성은(Kang 등, 2016) 농도별 시료 용액 $100 \mu \mathrm{L}$ 를 96-well plate에 분주한 뒤 $0.4 \mathrm{mM} \mathrm{DPPH}$ 용액 $100 \mu \mathrm{L}$ 를 혼합하여 10 분 동안 실온에서 차광하여 반응시킨 후 $517 \mathrm{~nm}$ 에서 흡광도를 측정하였다.

\section{Hydrogen peroxide 소거 활성}

Hydrogen peroxide 소거 활성은(Lee 등, 2015b) 시료 $80 \mu \mathrm{L}$ 에 $10 \mathrm{mM}$ hydrogen peroxide $20 \mathrm{~L}, 100 \mathrm{mM}$ sodium phosphate buffer (pH 5.0) $100 \mu \mathrm{L}$ 를 혼합하여 $37^{\circ} \mathrm{C}$ 에서 5 분 동안 반응시 킨 후 $1.25 \mathrm{mM}$ 2,2'-azino-bis (3-ethylbenzthiazoline)-6-sulfonic acid $30 \mu \mathrm{L}$ 를 첨가하여 $37^{\circ} \mathrm{C}$ 에서 10 분간 반응 시킨 후 $405 \mathrm{~nm}$ 에서 흡광도를 측정하였다.

\section{Nitric oxide 소거 활성}

Nitric oxide 소거활성은(Kim과 $\operatorname{Kim} 2012)$ 각 시료 $50 \mu \mathrm{L}$ 와 $10 \mathrm{mM}$ sodium nitroprusside $50 \mu \mathrm{L}$ 를 혼합하여 실온에서 3시간 동안 반응시켰다. 그 후 griess reagent $100 \mu \mathrm{L}$ 를 첨가한 후 실온 에서 15 분 동안 반응시킨 뒤 $540 \mathrm{~nm}$ 에서 흡광도를 측정하였다.

\section{Superoxide radical 소거 활성}

Superoxide radical 소거 활성은(Kim과 $\operatorname{Kim} 2016)$ 시료 $10 \mu \mathrm{L}$ 와 $50 \mathrm{mM}$ sodium carbonate buffer ( $\mathrm{pH}$ 10.5) $200 \mu \mathrm{L}, 3 \mathrm{mM}$ xanthine $10 \mu \mathrm{L}, 3 \mathrm{mM}$ ethylenediamine tetraacetic acid (EDTA) $10 \mu \mathrm{L}, 075 \mathrm{mM}$ Nitrobluetetrazolium $10 \mu \mathrm{L}, 0.15 \%$ bovine serum albumin solution $10 \mu \mathrm{L}$ 를 순서대로 넣은 뒤 잘 혼합하여 25 ${ }^{\circ} \mathrm{C}$ 에서 10 분간 반응시켰다. 그 후 $6 \mathrm{mU} / \mathrm{mL}$ xanthine oxidase $100 \mu \mathrm{L}$ 를 첨가하여 실온에서 20 분간 반응시킨 뒤 $6 \mathrm{mM} \mathrm{CuCl}$ $10 \mu \mathrm{L}$ 를 넣어 반응을 멈춘 후 $560 \mathrm{~nm}$ 에서 흡광도를 측정하였다.

\section{환원력}

환원력은(Lee 등, 2015b) 농도별 시료 용액 $200 \mu \mathrm{L}, 200 \mathrm{mM}$ sodium phosphate buffer (pH 6.6) $200 \mu \mathrm{L}$ 및 $1 \%$ potassium ferricyanide $200 \mu \mathrm{L}$ 를 순서대로 혼합한 뒤 $50{ }^{\circ} \mathrm{C}$ 에서 20 분간 반응시켰다. 반응시킨 혼합액에 $10 \%$ trichloroacetic acid 200 $\mu \mathrm{L}$ 를 첨가하여 반응을 정지시키고, 상층액 $100 \mu \mathrm{L}$ 를 96-well plate로 옮겨 $0.1 \%$ ferric chloride $20 \mu \mathrm{L}$ 및 증류수 $100 \mu \mathrm{L}$ 를 넣고 $700 \mathrm{~nm}$ 에서 흡광도를 측정하였다.

\section{Pancreatic lipase 억제 활성}

Pancreatic lipase 억제 활성은(Kwon 등, 2011) $10 \mathrm{mg} / \mathrm{mL}$ porcine pancreatic lipase (triacylglycerol acylhydrolase) $6 \mu \mathrm{L}$ 와 tris buffer $(\mathrm{pH} 7.0) 170 \mu \mathrm{L}$, 농도별 시료를 넣고 $37^{\circ} \mathrm{C}$ 에 서 15 분간 반응시켰다. 그 후 $10 \mathrm{mM} \mathrm{p}$-Nirtophenyl butyrate 4 $\mu \mathrm{L}$ 를 첨가하여 $37^{\circ} \mathrm{C}$ 에서 1 시간 동안 반응시킨 후 $400 \mathrm{~nm}$ 에서 흡광도를 측정하였다.

\section{통계방법}

모든 실험 결과는 3 회 반복 측정 후 평균값과 그의 표준편차로 나타내었다. 각 실험군의 성분과 항산화 및 항비만 활성 비교 
는 동백나무 겨우살이 무첨가군을 기준으로 하여 $p<0.05$ 수준 에서 Student's $t$-test로 유의성을 검증하였다.

\section{결과 및 고찰}

새로운 고부가가치의 동백나무 겨우살이 막걸리를 개발하기 위 하여 발효과정 중 동백나무 겨우살이의 함량을 달리하여 막걸 리를 제조하였고 이의 페놀성분, 항산화 및 항비만 등 생리 기 능성 변화를 비교 검토하였다. 동백나무 겨우살이를 첨가한 막 걸리의 총 페놀화합물 함량은 Table 1 에 나타내었다. 대조군(무 첨가 막걸리)의 총 페놀화합물의 함량은 $179.4 \mathrm{mg} \mathrm{GAE} / \mathrm{L}$ 이었 으며, $1 \%$ 첨가군은 $352.8 \mathrm{mg} \mathrm{GAE} / \mathrm{L}, 2 \%$ 첨가군은 $500.9 \mathrm{mg}$ $\mathrm{GAE} / \mathrm{L}, 4 \%$ 첨가군은 $716.3 \mathrm{mg} \mathrm{GAE} / \mathrm{L}$ 로 동백나무 겨우살이를 첨가한 막걸리의 페놀화합물 함량은 동백나무 겨우살이 첨가량 이 늘어날수록 유의적으로 증가하였는데 $(p<0.05)$, 이는 동백나 무 겨우살이에 페놀화합물이 풍부하게 함유되어 있기 때문으로 사료된다. 이러한 결과는 홍차를 첨가하여 제조한 막걸리 연구 (Cho 등, 2014)에서 홍차 첨가량이 증가할수록 페놀화합물 함 량이 증가하는 경향과 일치하였으며, 첨가물의 성분 함유량에 따른 차이로 사료된다. 총 플라보노이드 함량 역시 대조군이 $22.4 \mathrm{mg} \mathrm{RE} / \mathrm{L}$ 로 가장 낮았으며, 동백나무 겨우살이 첨가량이 단계적으로 증가함에 따라 유의적으로 높아져 $(p<0.05), 175.2$ $\mathrm{mg} \mathrm{RE} / \mathrm{L}$ 에서 $614.4 \mathrm{mg} \mathrm{RE} / \mathrm{L}$ 로 증가하였다(Table 1). 이 또한 동백나무 겨우살이의 높은 플라보노이드 함량에 기인하는 것으 로 판단되며, 아로니아를 첨가한 막걸리(Park 등, 2016)의 연구 결과에서도 유사한 결과가 보고되었다.

동백나무 겨우살이 막걸리의 radical (DPPH, hydrogen peroxide, nitric oxide, superoxide) 소거능 및 환원력은 Table 2과 같다. 동백나무 겨우살이 막걸리의 DPPH radical 소거능은 제조한 막 걸리를 증류수로 10 배 희석하여 측정하였는데, 겨우살이 첨가 량이 증가함에 따라 $\mathrm{DPPH}$ 전자공여능이 유의적으로 증가하여 항산화 능력이 높아지는 것을 알 수 있다. 특히 $4 \%(\mathrm{w} / \mathrm{v})$ 동
백나무 겨우살이 첨가군(84\%)의 경우, 양성대조군으로 사용한 $1 \%$ L-ascorbic acid (85.6\%)과 유사한 DPPH radical 소거능을 보였는데, 이는 10 배 희석한 시료를 측정한 점에서 동백나무 겨 우살이를 첨가한 막걸리가 상당한 효력이 있다는 것을 시사한 다. 당귀 추출물을 첨가한 막걸리(Lee 등, 2013b), 으름 열매를 첨가한 막걸리(Lee 등, 2013a)에서도 동백나무 겨우살이를 첨가 한 막걸리와 유사하게 항산화 능력을 가지는 부재료의 첨가량 이 증가할수록 $\mathrm{DPPH}$ 전자공여능이 유의하게 증가하는 경향이 나타났다. DPPH radical 소거능 결과와 같이 Hydrogen peroxide 라디컬 소거능 결과 역시 동백나무 겨우살이의 첨가비율에 따 라 증가하였다(Table 2). Hydrogen peroxide 소거능은 무첨가군 에서 $55.2 \%$ 로 가장 낮았으며, 동백나무 겨우살이 첨가량이 증 가함에 따라 그 활성이 유의적으로 증가하여 $1,2,4 \%$ 에서 각 각 $72.2,78.7,91.2 \%$ 의 활성을 나타내었다 $(p<0.05)$. 대조군으 로 사용된 $0.25 \%$ L-ascorbic acid는 $89.5 \%$ 를 나타내어 $4 \%$ 첨 가군(91.2\%)과 비슷한 활성을 나타냈다. Nitric oxide와 superoxide 소거능의 측정결과도 hydrogen peroxide 소거능 결과와 유사하 였는데, 각각 대조군은 64.6 와 $3.5 \%, 1 \%$ 동백나무 겨우살이 막 걸리 76.2 와 $82.8 \%, 2 \%$ 동백나무 겨우살이 막걸리 77.8 과 $97.2 \%$ 그리고 $4 \%$ 동백나무 겨우살이 막걸리 80.5 와 $98.6 \%$ 로 동백나무 겨우살이 함량이 증가할수록 항산화 활성이 유의적으 로 증가하였다 $(p<0.05)$ (Table 2). 시중에서 판매되고 있는 5종 류의 막걸리(Hong 등, 2009)에서 시판되는 무첨가 막걸리의 nitric oxide와 superoxide radical 소거능이 77.5-80\%를 나타내 어, 본 연구의 동백나무 겨우살이 첨가 막걸리(76-98\%)에 비해 낮은 활성을 보고하였다. Radical 소거능과 함께 항산화 활성의 중요한 지표로 사용되고 있는 환원력은 10 배 희석된 막걸리를 이용하여 측정하였는데, 환원력은 Potassium ferricyanide reduction 법을 사용하여 평가하는 것으로 흡광도 수치 그 자체가 시료의 환원력을 나타내며 높은 환원력을 가지는 물질은 흡광도의 수 치가 높게 나타난다. 본 연구에서 동백나무 겨우살이 무첨가군 의 경우 흡광도 값이 0.11 을 나타내는 반면 동백나무 겨우살이 첨가 막걸리는 $1,2,4 \%$ 첨가군의 흡광도 값이 각각 0.29 ,

Table 1 Total phenolic and flavonoid contents of Makgeolli added with Jeju camellia mistletoe

\begin{tabular}{crccc}
\hline \hline & \multicolumn{4}{c}{ Jeju camellia mistletoe (\% (w/v)) } \\
\cline { 2 - 5 } & \multicolumn{1}{c}{0} & 1 & 2 & 4 \\
\hline Total phenolic contents $\left(\mathrm{mg} \mathrm{GAE}^{1)} / \mathrm{L}\right)$ & $179.4 \pm 7.27$ & $352.8 \pm 6.58^{*}$ & $500.9 \pm 6.64^{*}$ & $716.3 \pm 5.27$ \\
Total flavonoid contents $\left(\mathrm{mg} \mathrm{RE}^{2} / \mathrm{L}\right)$ & $22.4 \pm 1.43$ & $175.2 \pm 1.63^{*}$ & $317.3 \pm 12.17^{*}$ & $614.4 \pm 8.56^{*}$ \\
\hline
\end{tabular}

${ }^{1)} \mathrm{GAE}$ (Gallic acid equivalent); ${ }^{2} \mathrm{RE}$ (Rutin equivalent)

All values are expressed as mean $\pm \mathrm{SD}(n=3) *$ Data were statistically different from the value of Makgeolli without camellia mistletoe $(p<0.05)$

Table 2 Antioxidant activities of Makgoelli added with Jeju camellia mistletoe

\begin{tabular}{cccccc}
\hline \hline \multirow{2}{*}{$\begin{array}{c}\text { Camellia mistletoe } \\
(\%(\mathrm{w} / \mathrm{v}))\end{array}$} & \multicolumn{2}{c}{ Scavenging activity $(\%)$} & \multirow{2}{*}{$\begin{array}{c}\text { Reducing Power } \\
(\times 0.1)\end{array}$} \\
\cline { 2 - 5 } & DPPH radical $(\times 0.1)^{1)}$ & Hydrogen peroxide & Nitric oxide & Superoxide anion & $0.11 \pm 0.001$ \\
1 & $14.5 \pm 0.68$ & $55.2 \pm 0.21$ & $64.6 \pm 1.38$ & $3.5 \pm 0.30$ & $0.29 \pm 0.003^{*}$ \\
2 & $41.3 \pm 1.01^{*}$ & $72.2 \pm 0.21^{*}$ & $76.2 \pm 2.79^{*}$ & $82.8 \pm 2.24^{*}$ & $0.41 \pm 0.004^{*}$ \\
4 & $61.8 \pm 0.23^{*}$ & $78.7 \pm 0.11^{*}$ & $77.8 \pm 3.60^{*}$ & $97.2 \pm 1.99^{*}$ & $0.62 \pm 0.010^{*}$ \\
\hline 0
\end{tabular}

${ }^{1)}(\times 0.1)$ : Sample was diluted with 10 times

All values are expressed as mean $\pm \mathrm{SD}(n=3) *$ Data were statistically different from the value of Makgeolli without camellia mistletoe $(p<0.05)$ 


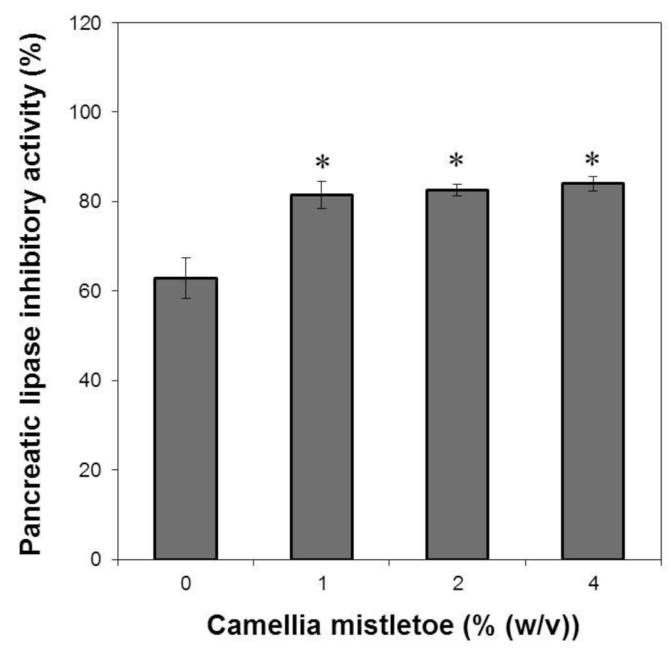

Fig. 1 Pancreatic lipase inhibitory activity of Makgeolli added with Jeju camellia mistletoe Each value is expressed as mean $\pm \mathrm{SD}(n=3) *$ Data were statistically different from the value of Makgeolli without camellia mistletoe $(p<0.05)$

$0.41,0.62$ 로 시료의 첨가량이 증가할수록 높은 환원력을 나타 냈다 $(p<0.05)$ (Table 2). 양성대조군으로 사용된 1\% L-ascorbic acid는 0.68 의 값을 보여 $4 \%$ 첨가군 $(0.62)$ 과 유사한 환원력을 나타내었으나, 이는 10 배 희석한 첨가군 시료의 측정값이라는 점에서 동백나무 겨우살이를 첨가한 막걸리가 매우 우수한 환 원력을 지니고 있음을 시사한다. 흑미를 첨가한 막걸리 $(\mathrm{Kim}$ 등, 2012) 연구에서도 무첨가군보다 20-60\% 높은 활성을 보고하였 다. 따라서 막걸리 제조 시 첨가된 부재료가 무첨가군의 항산 화 활성에 영향을 주는 한 요인으로 작용했을 것으로 판단된다. 상기 연구결과에서 동백나무 겨우살이의 총 폴리페놀 및 플라 보노이드 함량이 증가할수록 항산화 활성 또한 증가하는 것을 통해 동백나무 겨우살이에 포함된 기능성 성분과 항산화 활성 간의 깊은 상관관계가 있을 것으로 판단되었고, 여타 연구(Lee 등, $2015 \mathrm{a}$ )에서도 이와 같은 기능성 성분과 항산화 활성간의 높 은 상관관계를 보고하였다.

동백나무 겨우살이 막걸리의 지방분해 저해 효과를 측정하기 위해 pancreatic lipase를 이용한 방법을 사용한 결과는 Fig. 1과 같다. 무첨가 막걸리에서는 $62.9 \%$ 의 저해 활성을 보인 반면, 동 백나무 겨우살이 첨가 막걸리는 81.6-84.0\%의 저해 활성으로 무첨가군보다 약 1.3 배 높은 억제효과를 나타내었다. 또한 흑미 를 첨가한 전통주(Kwang 2010) 연구결과와 비교해볼 때 동백 나무 겨우살이를 첨가한 막걸리가 약 1.2 배 정도 lipase 활성에 대한 저해능을 확인할 수 있었다.

이상의 연구결과로부터 동백나무 겨우살이 첨가량이 증가할 수록 항산화 성분, 항산화력, pancreatic lipase 저해 활성이 유 의적으로 증가하였으며 $(p<0.05)$, 이는 동백나무 겨우살이가 막 걸리의 항산화력을 향상시켜 건강 지향적 제품개발을 위한 소 재로서 가치가 있다고 판단되며, 항비만 효과의 입증을 통해 심 화적인 연구개발의 기초자료로서 활용할 수 있는 가능성을 제 시하였다.

\section{초 록}

본 연구의 목적은 $0,1,2$, 및 $4 \%(\mathrm{w} / \mathrm{v})$ 의 제주 동백나무 겨우 살이를 첨가하여 발효시킨 막걸리의 함량 및 항산화 활성 그리 고 pancreatic lipase 저해 활성을 평가하는 것이다. 총 페놀 및 플라보노이드 함량은 제주 동백나무 겨우살이의 함량에 따라 증 가하는 경향을 보였다. 제주 동백나무 겨우살이의 첨가 결과 $\mathrm{DPPH}$, hydrogen peroxide, nitric oxide 및 superoxide onion 라디칼 소거 활성과 환원력은 상당한 증가를 보였다. 또한, pancreatic lipase 저해 활성은 제주 동백나무 겨우살이 첨가에 의해 유의하게 증가하였다. 이러한 결과로 보아 제주 동백나무 겨우살이가 막걸리의 항산화 및 pancreatic lipase 저해 활성을 향상시키는 물질로 사료된다.

Keywords 막걸리 - 제주 동백나무 겨우살이 - 총 페놀 함량 항산화 활성 - Pancreatic lipase 저해 활성

감사의 글 이 논문은 2014년(NRF-2014R1A1A2056292)과 2016년도 (2016R1A6A1A03012862) 정부(교육부)의 재원으로 한국연구재단의 지원을 받아 수행된 연구사업임

\section{References}

Baek CH, Choi JH, Choi HS, Jeong ST, Kim JH, Jeong YJ, Yeo SH (2013) Quality characteristics of brown rice Makgeolli produced under differing conditions. Microbiol Biotechnol Lett 41: 168-175

Cho JY, Shim HJ, Jo YL, Ma SJ, Kim SJ, Moon JH, Park KH (2014) Fermentation characterization and chemical composition of Makgeolli prepared by the addition of Black Tea. The Korean The Tea 20: 79-85

Choi KW, Lee JK, Jo HJ, Lee KJ, Yoon JA, An JH, Chung KH (2013) Fermentation characteristics of Makgelli made with loquat fruits (Eriobotrya japonica Lindley). J Korean Soc Food Sci Nutr 42: 975-982

Hong YH, Bae SH, Jung EY, Son HS, Shin KS, Kwon KH, Suh HJ (2009) Radical scavenging activities of Korean traditional rice wine, Takju. J Food Sci Nutr 14: 109-115

Kang DH, Kim MY (2015) Comparative phenolic composition and antioxidant properties of Honey and Honeycomb extracts. J Life Sci 25: 1169-1175

Kang DH, Park EM, Kim JH, Yang JW, Kim JH, Kim MY (2016) Bioactive compounds and antioxidant activity of Jeju Camellia Mistletoe (Korthalsella japonica Engl.). J Life Sci 26: 1074-1081

Kang SJ, Chung SK (2012) Antioxidant and antimicrobial activities of Korean mistletoe (Viscum album var. coloratum) extracts against food poisoning bacteria. Korean J Food Preserv 19: 919-924

Kim BH, Eun JB (2012) Physicochemical and sensory characteristics of makgeolli with pomegranate (Punica granatum L.) juice concentrate added. Korean J Food Sci Technol 44: 417-421

Kim JH, Kim MY (2012) Enhancement of bioactive components content and the antioxidant activity of green tea after continuous anaerobic incubation. J Agr Sci Tech 14: 837-844

Kim JH, Kim MY (2016) The potential use of citrus juice waste as sources of natural phenolic antioxidants. J Appl Pharm Sci 6: 202-205

Kim OS, Park SS, Sung JM (2012) Antioxidant activity and fermentation characteristics of traditional black rice wine. J Korean Soc Food Sci Nutr 41: $1693-1700$

Kim SY, Park EJ (2015) Fermentation characteristics of Shindari added with Carrot. Korean J Food Cook Sci 31: 9-17 
Kwang JY (2010) Development and quality feature of colored tradition wine fermented using black rice. MS Thesis. Dong-A University

Kwon TH, Kim JK, Kim TW, Lee JW, Kim JT, Seo HJ, Kim MJ, Kim CG, Jeon DS, Park NH (2011) Antioxidant and anti-lipase activity in Halocynthia roretzi extracts. Korean J Food Sci Technol 43: 464-468

Lee AR, Oh EY, Jeong YJ, Noh J-G, Yoon H-S, Lee KY, Kim YG, Eom H. (2015a) Quality characteritic and antioxidant activity of aronia (Aronia melanocarpa) makgeolli prepared with the additive methods. Korean J Food Nutr 28: 602-611

Lee HJ, Do JR, Kwon JH, Kim HK (2010) Antioxidant effects of Viscum album L. extracts by extraction conditions. J Korean Soc Food Sci Nutr 39: $14-19$

Lee JE, Kim JH, Kim MY (2015b) Changes in phenolic composition, antioxidant and antidiabetic properties of Jeju Citrus sudachi as influenced by Maturity. J Life Sci 25: 1311-1318

Lee JK, Jo HJ, Kim KI, Yoon JA, Chung KH, Song BC, An JH (2013a) Physicochemical characteristics and biological activities of Makgeolli supplemented with the fruit of Akebia quinata during fermentation. Korean J Food Sci Technol 45: 619-627

Lee JM, Lee HN, Chang YH (2013b) Quality characteristics of Makgeolli using angelica gigas nakai water extracts. J East Asian Soc Dietary Life 23

Park CH, Park CG, Bang KH, Park HW, Seong NS (2003) Plant growth and anatomical characteristics of Korean mistel (Viscum album var. coloratum (kom.) Ohwi). Korean J Medicinal Crop Sci 11: 122-126

Park MJ, Kim HK, Choi KK, Koo BY, Lee SK (2016) Fermentation characteristics of Makgeolli containing Aronia (Aronia melanocarpa, Black chokeberry). Korean J Food Sci Technol 48: 27-35 